\title{
ИНГИБИТОРЫ КАРБОКСИЛЭСТЕРАЗЫ \\ НА ОСНОВЕ ПОЛИФТОРАЛКИЛСОДЕРЖАЩЕГО 2-АРИЛГИДРАЗИЛИДЕН-1,3-ДИОНОВОГО СКАФФОЛДА
}

\author{
Я.В. Бургарт ${ }^{1}$, Г.Ф. Махаева², С.В. Лущекина ${ }^{2,3}$, Е.В. Щегольков², \\ Н.П. Болтнева ${ }^{2}$, Н.А. Елькина', Е.В. Рудакова ${ }^{2}$, Н.В. Ковалева ${ }^{2}$, \\ О.Г. Серебрякова², В.И. Салоутин'
}

\author{
${ }^{1}$ Институт органического синтеза им. И.Я. Постовского УрО РАН, \\ 620990, Россия, Екатеринбург, ул. С. Ковалевской/Академическая, 22/20. \\ ${ }^{2}$ Институт физиологически активных веществ РАН, \\ 142432, Россия, Черноголовка, Северный проезд, 1. \\ з Институт биохимической физики им. Н.М. Эмануэля РАН \\ 119334, Россия, г. Москва, ул. Косыгина, д. 4.
}

DOI: 10.19163/MedChemRussia2021-2021-61

E-mail: burgart@ios.uran.ru

В докладе обсуждается перспективность создания на основе полифторалкил2-имино-1,3-дионового скаффолда новых активных и селективных модуляторов карбоксилэстеразы (КФ 3.1.1.1, КЭ) как инновационных средств коррекции метаболизма, повышения эффективности и рационального использования фармакологических препаратов, содержащих сложноэфирные группировки, и средств терапии ряда метаболических заболеваний, таких как ожирение, диабет 2-го типа, атеросклероз. Данный скаффолд объединяет два фармакофорных фрагмента - полифторкетонную и 1,2-дионовую группы, ответственных за ингибирование КЭ. Отличительной особенностью полифторалкил-2-имино-1,3-дионового скаффолда является замена одной карбонильной функции 1,2-дионового фрагмента на биоизостерную иминогруппу, в качестве которой мы используем арилгидразилиденовый заместитель. Рассмотрены методы синтеза алкил-2-арилгидразинилиден-3-оксопропионовых кислот (I), их алкиловых эфиров (II), производных с остатком природного спирта (III), а также амидов (IV). Определены специфичные характеристики эстеразного профиля соединений (I-IV), найденные при их биологическом тестировании и молекулярном моделировании. Показаны различные аспекты антиоксидантного действия кислот (I) и их производных (I-III) в зависимости от их строения.

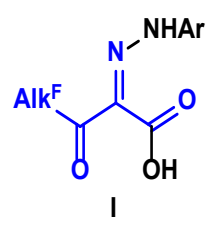<smiles>COC(=O)C(=NN)C(=O)[AlH2]</smiles>

II

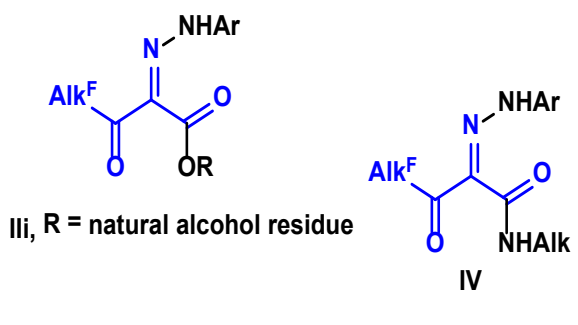

Работа выполнена при финансовой поддержке РФФИ, грант 20-03-00312а.

$$
-61-
$$

